Abstract: The subject of the paper is the analysis of three doublefaced cornices excavated in the main courtyard of the 'Hellenistic' House. The decorated blocks constitute a very rare example of architectural embellishment, the more so that they come from a circular structure. The aim of the paper is to present possible types of buildings the cornices originally might have been parts of.

Keywords: Nea Paphos; tholos; circular building, 'Hellenistic' House; architectural decoration

\title{
Introduction
}

During 2012 and 2013 the Polish Archaeological Mission at Kato Paphos of Warsaw University, directed by Dr Henryk Meyza, conducted two excavation campaigns in the 'Hellenistic' House. This extensive edifice, dated to the late 1st - early 2nd century AD (Meyza et al. 2017, 398, 403, 411 ) is located in the southern part of Maloutena, in the residential area of Nea Paphos, an ancient city on the south-west coast of Cyprus developed in the Hellenistic and Roman period (Pl. 1: 1). The house, built up around two courtyards, originally occupied one insula of the Hellenistic grid of streets. The smaller courtyard lies in the western part of the edifice (Meyza et al. 2012, 407, 412-418; Brzozowska-Jawornicka forthcoming a), the main one is situated in the central part of the building and took the form of a square or rectangular peristyle (Pl. 1: 2) (Daszewski 1991, 82; Brzozowska-Jawornicka forthcoming b). 
A short time after, probably in the second half of the 2nd century AD, the whole city along with many Paphian residences was destroyed by an earthquake (Hayes 1997, 536; Papuci-Władyka 2008). After the destruction, a new building, the Villa of Theseus, was erected in Maloutena occupying almost six insulae, including the northern part of the insula where at the time the ruined 'Hellenistic' House had been standing. Its central courtyard was filled with huge amounts of rubble and debris. During excavations it turned out that it contained many pieces of architectural decoration, e.g. capitals, cornices, bases etc. Some of them could be connected with the original structure of the 'Hellenistic' House (Brzozowska-Jawornicka forthcoming b), but a lot of fragments of carved embellishment had most probably once belonged to other destroyed buildings from the neighborhood. This main courtyard was transformed into a warehouse for easily accessible building materials and architectural decorated elements from the whole vicinity.

Among the elements of the architectural embellishment excavated in the main courtyard there are three unusual cornices (Meyza 2015, 452), which will be discussed below.

\section{The double-faced cornice}

The three analyzed fragments present a repetitive set of common features (Pl. 2: 1). Firstly, they share the same scale and similar size: their height equals $20.5 \mathrm{~cm}$, the other dimensions, i.e. width and depth, are different (HH/12 F.27.19: 60.5 x 49cm; HH/12 F.27.1: 47 x 51.5cm; HH 1. F.14/13.4: $51.5 \times 52.5 \mathrm{~cm}$ ), which results from their destruction (described below). Secondly, they are equipped with two diverse cornice moldings on two opposite sides. Thirdly, the fragments are curvilinear: the inner cornice is concave, while the outer one is convex. ${ }^{1}$ Last but not least, their top flat surface was originally covered with mortar. Therefore it may be assumed that the three pieces of double-faced cornices most probably belonged originally to one architectural ensemble from a circular structure. No remains of that kind were found in the 'Hellenistic' House, so the cornices must have been thrown out there with debris from the neighborhood. ${ }^{2}$

${ }_{1}$ Dr Henryk Meyza was the first to notice the curvature of the presented blocks. I would like to thank him for pointing them out to me and supporting me in this as well as in many other studies of the architectural decoration from Cyprus.

2 Remains of a circular pool were discovered in the main courtyard of the 'Hellenistic' House (Meyza et al. 2017; Romaniuk 2017), but of different diameter than the curvatures of the fragments of the double-faced cornice. 
They are also damaged to a similar extent. Their original surfaces are badly weathered and so is the mortar on their upper surface (in the case of the HH 1. F.14/13.4 block it is almost completely missing). However, the biggest damage to the blocks was not due to the passage of time or the destructive effects of atmospheric factors, but it was intentionally caused by men. At the beginning the cornices belonged to a presently unknown building, which was destroyed at an unspecified time. Then they were reused in a completely different but also unknown building. The second edifice in which the cornices were embedded must have differed from the first one, as the geometry of the blocks had to be changed to incorporate them into a new structure against their true 'nature'. It seems that it was rectilinear, as the curvatures of both the internal and external cornices were flattened to acquire a new, straight shape.

Presently it is impossible to establish even the approximate date of the erection of the original round building for which the cornices were carved. Similarly, the subsequent building they were secondarily mounted into is unknown, besides only one piece of information that it was most probably a rectilinear structure. The date of its construction remains unidentified. The only credible assumption that can be made states that both buildings must have been erected and ruined before the destruction of the 'Hellenistic' House (terminus ante quem - mid-2nd century AD (see above Meyza et al. 2017, 398, 403, 411)), as the cornices were discovered in the house's main courtyard transformed into a rubble dump.

The re-cutting of the blocks resulted in a partial destruction of their moldings - the upper, most protruding parts, were cut off, which makes their identification difficult. However, their lower parts indicate that they were most probably composed of rather a common basic sequence of moldings.

In the case of the outer convex cornice, its preserved part consists of, from the top, flat grooved modillions alternating with square hollow modillions, cavetto, squared astragal, and another cavetto. On the basis of analogies from Paphos, such as the cornice from the western courtyard of the 'Hellenistic' House (Brzozowska-Jawornicka forthcoming a; forthcoming b) and other ancient Cypriot cities, e.g. the cornice from the Agora of Amathus (Vanderstar 1997, B, 25, P1. MK3), the design of the upper missing part of the convex cornice may be suggested as follows: a fillet, cyma recta, ovolo, and corona. The whole set is a local version of a Corinthian cornice. 
The preserved part of the inner concave cornice is designed as follows: presumably a corona (only a small fragment of a soffit is preserved), a fillet, a cavetto, a squared astragal, an ovolo, a squared astragal and dentils (P1. 2: 2). The upper missing moldings might have been composed of a fillet, a cyma recta, and a drip cornice or a corona with a soffit - the degree of the destruction makes it impossible to unequivocally establish the original sequence of moldings, but the second variant seems more probable.

It is necessary to emphasize that the Cypriot carved architectural decoration did not precisely follow the classical canon, which can be seen e.g. by mixing the architectural orders described below, but also in moldings of particular fragments of entablatures or capitals deviating from model solutions (Brzozowska-Jawornicka forthcoming b). For this reason, the reconstruction of the lacking upper parts of the analyzed cornices is only approximate and cannot be taken for granted.

The second variant is still recognizable in two unpublished and unfortunately dilapidated fragments of cornices found in the area of the 'Hellenistic' House (P1. 2: 2). Another example of an Ionic cornice with dentils may be found in the Paphos district Museum (Vanderstar 1997, $\mathrm{B}, 34, \mathrm{Pl}$. IK1). Its exact provenance is unknown and, despite the destruction of its upper part, it still presents a much more decorative form than the three pieces found in the courtyard of the 'Hellenistic' House - the soffit is embellished with three busts.

A lot of small fragments of both variants of cornices (with modillions or dentils) were found in Nea Paphos (e.g. Fuduli 2015, 37-41, cat. nos 41-51), but they are small and too destroyed to constitute a reliable analogy for recreation of the original form of the three analyzed cornices. However, a considerable number of such cornices proves their popularity and widespread usage. A small fragment found in the dromos in the area of the Garrison's Camp and marked with Sc. 1803 number (Fuduli 2015, 41, cat. no. 51) is also very interesting for another reason: judging only from a photograph it seems to be a part of a rounded, concave structure.

There is also a third variant of the arrangement of cornice moldings (Pl. 2: 2): the Temple of Aphrodite in Amathus was crowned with a very richly decorated entablature with a cornice composed of both modillions and dentils (Vanderstar 1997, B, 75-76, Pl. MK1d). The third variant seems rather unlikely for the cornices found in the 'Hellenistic' House, as such a design requires a much higher cornice than the three analyzed blocks.

It is worth noting that cornices with flat grooved modillions alternating with square hollow modillions originated in Hellenistic Alexandria 
(McKenzie 1990, 93-94; Pensabene 1993, 99-103, Tav. 6.33-34, 92-99, 101.960-965, 131-133, 135; McKenzie 2007, 87-89, Figs 139-140; Tkaczow 2008, Pls LXIII, cat. no. 608) and spread in the areas under the influences of the Ptolemaic Empire: Egypt itself (e.g. Pensabene 1993, Tav. 10.65-68, 14.86-89; Czerner 2009, 14-16, Pls X-XI), Cyprus as indicated above, Cyrenaica (Pesce 1950, Figs 15-17, Tav. VIII C, XIII A; McKenzie 1990, Pl. 222) and Nabataea (McKenzie 1990, Pls 26b, 39a-b, 119).

A similar phenomenon occurred in the case of the Alexandrian cornices with dentils (selected examples from Alexandria and Egypt: McKenzie 1990, Pls 175b, 179c, 211b-d, 215 c-d; Pensabene 1993, Tav. 3.19, 9091; Tkaczow 2008, Pls XIII.1, LXIV, cat. no. 629, LXV, cat. no. 635; Czerner 2009, 14-15, 20-21, Pls VIII-IX) later found in Cyrenaican cities (e.g. Pesce 1950, Figs 13-14, Tav. XIII B) and Petra (e.g. McKenzie 1990, Pls 79, 94, 151).

However, the most characteristic type of the Corinthianising cornice of the Alexandrian architecture was the rich variant with dentils under the modillions (McKenzie 1990, Pls 206g, 214d, h, 215 a-b, 216 a, d, 217 c; Pensabene 1993, Tav. 3.19, 94.886-888, 96.916-920, 97.921-923; McKenzie 2007, 87-89, 93, Figs 150-151) described above on an example of the cornice from the Temple of Aphrodite in Amathus and also known from Cyrenaica (Pesce 1950, Figs 13-14, Tav. XIII A; McKenzie 1990, Pls 222 a-b, d-e).

It has been suggested that the double-faced cornices could have been fragments of a lintel installed over a window or a door (Meyza 2015, 452). However, window lintels were usually carved out of one single block, i.e. a single stone or wooden beam covered the whole opening of a window. Many monolithic window and door lintels from wealthy Cyrenaican residences like the Casa delle Quattro Stagioni or the House of Leukaktios may serve as good examples. In the latter case if the openings of wide doors exceeded $170 \mathrm{~cm}$, they were covered with arches (Kraeling 1962, Pls XXVIa, XXVIIa-c; Rekowska 2012, 165, 168-171, Pl. 5).

The three analyzed blocks from the 'Hellenistic' House are rather short (maximum length $60 \mathrm{~cm}$ ). As separate elements they are too short to constitute a single lintel - the window openings would be too narrow. Moreover in their bottom surfaces there are no slots for pivot hinges that were usually cut in the underside of lintels, e.g. in the examples from the House of Leukaktios (Rekowska 2012, 170, P1. 5). Together the three cornices form a beam of at least $180 \mathrm{~cm}$ in length, which seems to be too long for a window 
lintel. They might have been placed above a door opening, but in such a case they would have to have rested on another element, most probably a wooden beam.

Pieces of a very richly decorated door lintel were found in the House of Aion not far away from the 'Hellenistic' House (Brzozowska-Jawornicka 2016, 152, 160-161, Pls 2.2, 5). They are also quite short and originally must have been placed on a wooden beam. Two of the four discovered fragments constituted the corner blocks with moldings closing the decoration on the edges of the door.

This type of corner double-faced cornices has not been found yet. It of course does not exclude the possibility of finding them in the future, but presently there are no such pieces which could confirm their constituting a lintel. Even more importantly, all the above-mentioned examples of lintels were decorated only on their external sides, and not on two opposite sides, as in the case of the double-faced cornices.

It seems more probable that the analyzed blocks were fragments of a double-faced cornice that crowned a circular unpreserved entablature decorated on both the internal and external sides. Similar double-faced cornices, although straight not rounded and decorated with modillions on both sides, were found in Alexandria and identified as pieces of a portico or a colonnade from the 2 nd or 1 st century BC (Pensabene 1993, 500-501, Tav. 92.863-864A).

The massive scale of the damage of the cornices, i.e. their weathered surfaces and moldings as well as the re-cutting of their curvatures to a new straight shape, hindered establishing their primary geometry, but on the basis of the curvature measurements we managed to determine that the cornices were parts of a circular structure of approximately $550-600 \mathrm{~cm}$ in diameter (P1. 2: 3). Establishing the diameter was essential, as it is basic information about the original building which then may indicate its size, and allow us to state a possible plan for a general and hypothetical reconstruction.

It is very tricky and risky to estimate the height of this structure merely on the basis of the height of the three cornices, because, as mentioned above, the Cypriot builders did not necessarily follow the classical canon. The cornices themselves were not carved exactly according to the rigid traditional standards, and neither was the whole set they belonged to.

Having no other indications, we may hypothesize that the moldings on two sides of the blocks point towards to two orders: dentils were

3 The initial measurements suggested a diameter of 300cm (Meyza 2015, 452). Repeated measurements allowed verifying this data. 
usually parts of the Ionic cornice, whereas modillion cornices were used in the Corinthian entablatures.

In both orders the height of the cornices equals more or less one module, i.e. the diameter of the column shaft at its base. If we assume that the whole assemblage roughly follows the canon (Vitr. De Arch. 3.5), we may compute its purely hypothetical height on the basis of the height of the analyzed cornices $(20.5 \mathrm{~cm})$. In the case of the Ionic order, the column would have measured $211.5 \mathrm{~cm}$, the entablature $46 \mathrm{~cm}$, and the total assemblage $257.5 \mathrm{~cm}$. The Corinthian order would have been almost equal: the column height would have been $205 \mathrm{~cm}$, the entablature 51.25 and the complete set 256.25. Both results seem rather short and modest, which may suggest that the supports could have been higher than it was assumed in classical orders. It is also possible that the supports stood on a socle, a podium or pedestals which would have raised the total height of the complete structure by one-fifth of the total ensemble height: about half a meter.

Just for this purely hypothetical study it may be assumed that the presented above calculations concerning the cornices are valid. If these assumptions are correct, the double-faced cornices, quite a sophisticated and rather rarely used arrangement, surmounted a circular structure measuring approximately $260 \mathrm{~cm}$ (about $300 \mathrm{~cm}$ with pedestals or a socle), most probably a low colonnade or portico.

It is worth emphasizing that the double-faced cornices were designed to be viewed from both the internal and the external sides, which, although an apparent attribute, might be easily overlooked. That is why they could not have belonged to façades which were intended to be seen only from one, obviously the front, side. It means that all the edifices equipped with richly decorated elevations where a curvilinear design occurred cannot be taken into account as a potential original placement of the cornices: e.g. monumental gates, tetrapylons, triumphal arches or the scenae frons of theatres. The diameter of the cornices curvatures and their size indicate that they must have belonged to a relatively small circular structure/building, which in turn excludes big spherical or elliptical edifices like theatres or amphitheaters.

The question is: what kind of a spherical edifice did this colonnade belong to?

There are many buildings or parts of bigger complexes that could have been erected on a circular plan. Below is a short analysis of selected most obvious and popular types of edifices in which a round structure constitutes 
the basic design. They all originated in the Hellenistic and Roman world to which Cyprus belonged.

\section{Tholoi}

A tholos, a circular building covered by a conical roof, constitutes the most obvious association with a round building in the Greco-Roman world. The oldest tholoi are dated to the Archaic period. They could have taken several different forms: a rotunda with a round solid wall, a monopteros with a roof resting on a circular row of columns, or a round peripteros with a cella inside the spherical colonnade. They were built very rarely because erecting a tholos was much more expensive and technically demanding than a rectilinear building. The tholoi usually were used to shield a sacred place or an offering. Such a purpose demanded an appropriately rich architectural frame, and the extraordinary form and the circular plan allowed conducting experiments concerning both its form and embellishment (Campbell 2007, 691-692).

\section{Memorials}

Large memorials erected in the important Greek sanctuaries in the 4th and 3rd century BC are among the best known tholoi. Their function is not entirely clarified, but it seems that they were meant to commemorate royal families, like the Philippeion in Olympia or the hero-gods like Asklepios in the Tholos at Epidauros. To underline their special role, their architectural decoration is sophisticated, with special meaning presented in reliefs of e.g. metopes or friezes. The earliest known exemplars of the Corinthian order are in the interiors of the tholoi (Fedak 2006, 72-76).

The Tholos at Delphi in the central part of the Marmariá terrace, which belongs to the sanctuary of Athena Pronaia, is one of the most famous Greek circular shrines. Very carefully designed with slender proportions, this tholos presents the form of a round Doric peripteros with the interior decorated by Corinthian Columns tangent to a cella wall (Seiler 1986, 40-55, Figs 19-23; Fedak 2006, 72-73; Winter 2006, 378, Figs 187-8).

The Tholos at Epidauros in the sanctuary of Asklepios constitutes another example of a round Doric peripteros and is considered to be the best known Greek circular building with very rich architectural embellishment (Pl. 3: 1). It has a more complex interior, as in the cella the central space is underlined with an internal Corinthian colonnade. More importantly, this colonnade was 
topped with a double-faced complete entablature (an arrangement similar to the three cornices found in the 'Hellenistic' House) which supported richly decorated stone coffers on the external side and a conical roof covered with heavy marble tiles with a centrally placed akroterion on the internal side (Seiler 1986, 56-88, Figs 26-35; Fedak 2006, 72-74; Winter 2006, 378, Figs 189-190).

The Philippeion in Olympia, an Ionic round peripteros, is characterized by a plan similar to the Tholos at Delphi - the internal face of the cella wall was decorated with Corinthian order, but in this case with engaged halfcolumns. The cella wall is crowned with a double-faced entablature, just like in the Tholos at Epidauros (Seiler 1986, 89-103, Figs 36-40; Fedak 2006, 74-75; Winter 2006, 379, Figs 192-193).

The Arsinoeion in the sanctuary of the Great Gods in Samothrace presents a different form of a tholos - it is the biggest known Greek rotunda with a solid wall divided into a high socle topped by a plain wall decorated with Doric pilasters. They support a Doric entablature, but the scale of the latter is compatible with the size of the whole tholos, not with the pilasters. The composition of the interior is similar to the exterior - a high socle supporting half-columns but of a Corinthian order. The roof was most probably wooden, made of converging beams (Seiler 1986, 107-115, Figs 43-46; Fedak 2006, 75-76; Winter 2006, 379-380, Figs 194-196).

It seems highly unlikely that the three double-faced Paphian cornices could have been parts of a tholos like the big memorials in the important sanctuaries described above. The analyzed blocks were found in the middle of the residential area, far away from any sacred place. Their moldings are very common in Nea Paphos - quite opposite to the most elaborated decoration of the Greek tholoi. Although the circular double-faced entablatures from the Tholos of Epidauros or the Philippeion in Olympia constitute a rare analogy to the analyzed cornices, the proportions of these buildings are entirely different than those of the hypothetical round Paphian structure. The ratio between the height of the inner columns together with the entablature they supported to the diameter of the colonnade is 0.86 in the Tholos at Epidauros. In the Philippeion in Olympia this proportion is 0.95 , but instead of an inner colonnade there is a cella wall topped with double-faced entablature. The estimated ratio of the height to the diameter of the Paphian hypothetical round structure oscillates from 0.43 (a colonnade with an entablature) to 0.5 (a colonnade with an entablature standing on a podium, socle or pedestals). 


\section{Small Tholoi}

A small slender tholos usually placed on a high podium constitutes the second most popular type of a round monument, examples of which may be found in many cities of the Greco-Roman world. Such little shrines served different purposes e.g. they were monuments commemorating victories, tombs, small shrines or elements of bigger complex buildings.

The choragic Monument of Lysicrates in Athens, dated to the second half of the 4th century BC and commemorating the victory of a boys' choir sponsored by the wealthy Athenian citizen Lysicrates, is probably the most famous tholos of that kind (Pl. 3: 2). Its form is modelled on the basis of the podium-tombs of Asia Minor: a high square socle supporting a small and slender tholos on a circular platform. The tholos takes the form of a rotunda embellished with six Corinthian half-columns supporting Ionic entablature. The latter was crowned with a monolithic marble roof of a conical shape with its peak underlined by a central finial topped with other unpreserved decorative elements (Fedak 2006, 71, 75; Winter 2006, 377, Figs 185). The ratio of the height of the tholos (up to the upper edge of the cornice) to its diameter is 1.85 .

This monument is considered to be one of the first small tholoi, a precursor of the type replicated later in many other buildings of various functions (Lyttelton 1974, 35, Fig. 39), e.g. in the Babbius Monument in Corinth in a form of a Corinthian monopteros (Lytellton 1974, 278, 280 - 280, Pl. 206) or in the Monument of the Julii in St Rémy-de-Provence. The general appearance of the latter is much more decorative, as e.g. the podium is composed of several stories including a dado decorated with mythical scenes and an arched tetrapylon. The tholos takes the form of a Corinthian monopteros surmounted by quite a steep conical roof (Fedak 2006, 71, 75; Winter 2006, 395, Fig. 231).

\section{Nymphaea}

The nymphaea built in many ancient cities during the Hellenistic and the Roman periods took many different forms, sometimes based on circular plans. The one founded in Olympia by Herodes Atticus about AD 160 is characterized by quite a complex design (Pl. 3: 3). The monument consists of two terraces: the upper one with a semi-circular exedra containing a fountain basin, the lower one with a long rectangular basin flanked on each side by two small tholoi erected as Corinthian monopteroi with eight columns supporting an entablature and a conical roof (Lyttelton 1974, 277- 
278, Fig. 47, P1. 202). They strongly resemble buildings like the Monument of Lysicrates.

\section{Tholoi in the courtyards of residences}

Another type of a small circular monument that most probably derived from the small shrines like the Monument of Lysicrates can be viewed in specific depictions in the wall-paintings in Italy in the so-called Second Style, phase I, c. 90-50 BC (Lyttelton 1974, 20; McKenzie 2007, 90). In many Pompeian or Campanian rich residences walls of rooms were decorated with elaborate paintings often presenting a repetitive scene: a colonnaded court seen through a broken or hollow pediment framing a slim tholos placed in the center of the composition. The tholos usually takes the form of a Corinthian monopteros surmounted by a tent roof with a decorative element on the top. Examples of such scenes may be found in Pompeii, e.g. in the House of the Labyrinth, in the Villa of the Mysteries or in the House of Julia Felix, in Boscoreale in the Villa of P. Fannius Sinistor or in Villa Oplontis in Torre Annunziata (Lyttelton 1974, 18-20, 22-23, 50, 210-211, Pls 16-17, 27-28; McKenzie 2007, 90, 99, 100-101, 104, Figs 143, 161, 171).

A similar architectural design composed of a tholos framed with broken pediment is used in monumental façades of the rock-cut edifices from Petra: tombs - Khasneh, 1st century BC, and the Corinthian Tomb, AD 40-70, and the triclinium - the Deir, AD 40-70 (Lyttelton 1974, 68-69,76-78, 8083, Pls 1, 15, 75; McKenzie 1990, 140-143, 152-154, 159-161, Pls 79-80, 116, 138-139, 141d; McKenzie 2007, 89, Fig. 141, 97-98, 101).

A solid rotunda constitutes this form of the Petra tholoi (Pl. 4: 1). It is crowned with a tent roof which is topped with a capital supporting a lidded urn. Their walls are embellished with engaged columns crowned with the entablature and roof. The half-columns are surmounted by type 1 Nabatean capitals in the case of the Deir and Corinthian capitals in the tholoi of Khasneh and the Corinthian Tomb. The top capitals bearing the urn present appropriate styles.

Narrow proportions are a very characteristic attribute of the Petra tholoi (McKenzie 2007, 97): the ratio of the height of the tholos (up to the upper edge of the cornice) to its diameter varies from 1.6 through 1.5 to 2.4 for the Corinthian Tomb, Khasneh and the Deir respectively. ${ }^{4}$ The depictions of

\footnotetext{
4 Writer's estimated measurement on the basis of generally available drawings (McKenzie 1990, Pls 80, 139) and photographs. The Corinthian Tomb is very weathered so the measurements of its façade are highly approximate.
} 
the Italian tholoi do not allow for such calculations, as quite often their lower parts are covered with other elements of the scene, but it seems that their proportions could be similar.

The tholoi listed above are dated from the 1st century BC (the Pompeian monopteroi and the tholos of Khasneh) to the 1st century AD (the tholoi of the Corinthian Tomb and the Deir) However, there is one depiction of a similar tholos of an older origin dated to the 3rd or 2nd centuries BC: on the east wall of chamber 3 of the Tomb I at Moustapha Pasha necropolis in Alexandria (Lyttelton 1974, 50; McKenzie 2007, 73, 109-111, Figs 107, 184-185). Only the upper part of the scene is preserved, but a tholos with a sloping roof is still visible, most probably standing in a garden with blue sky above it.

Another example of a tholos from Alexandria is known only thanks to its description in Deipnosophistae by Athenaeus, in which he wrote about Thalamegos, the luxurious river boat of Ptolemy IV Philopator (221-204 BC). On the upper deck there was a monopteros with a statue of Aphrodite. Sleeping apartments surrounded this little circular shrine creating a wellknown pattern of an open courtyard around a tholos (Ath. V, 205, e; Lyttelton 1974, 20, 50; Pfommer 1999, frontispiece, 93-95, 106, Fig. 148). If such an arrangement occurred on a ship serving as a floating palace, it seems highly likely that similar colonnaded courtyards with tholoi might have been built in rich Alexandrian palaces or residences, even if there is no physical proof of their existence (Pfommer 1999, 135-139, Fig. 184).

The description of the tholos on the boat of Ptolemy Philopator also provides a hint concerning the function of such small monuments - little shrines enclosing a statue of a goddess or a god decorating peristyle courts of residences.

According to recent studies, Ptolemaic Alexandria played the key role in the development of the art and architecture in the eastern Mediterranean in the Hellenistic and Roman periods (Lyttelton 1974, 50, 76; McKenzie 1990, 85-100, McKenzie 2007). Many ideas, designs, trends and tendencies spread from Egypt to territories under the influence of the Ptolemaic Empire: Cyrenaica, Nabataea and Cyprus. As the oldest known depiction of a tholos in a garden is known from Alexandria, it is possible that the Capital of Egypt could have been the source of the arrangement of the colonnaded court with a tholos in the middle. The rock-cut façades of tombs in Petra may reflect this design similarly to the scenes of tholoi depicted in Pompeian paintings (McKenzie 2007, 35, 103). 
It is very tempting to link the three fragments of the double-faced cornices with a small circular shrine presenting one of the types presented above. The third variant, a tholos in the middle of a peristyle, seems to be particularly alluring. On the first sight it seems quite a good hypothesis a monopteros placed in the middle of the main colonnaded courtyard of the 'Hellenistic' House - a rich residence located in the capital of Cyprus. At the time the island remained under strong cultural and artistic influences of Egypt, although it no longer belonged to the non-existing Ptolemaic Empire. So the typical Alexandrian arrangement of a peristyle courtyard with a tholos would not be a surprise.

However, there are at least two major conclusive counterarguments which force us to reject this theory. Firstly, as mentioned above, there are no traces linking the cornices with any structure of the 'Hellenistic' House, or with any other known Paphian residence. Secondly, and more importantly, the slender tholoi from Petra or from the Pompeian wall-paintings, which were derived from the buildings like the Monument of Lysicrates, are characterized by proportions different than the hypothetical structure of the analyzed blocks. The double-faced cornices simply come from a building of a different form and nature.

\section{Macella}

A similar arrangement of a courtyard with a circular building in the middle was sometimes used to design macella - Roman indoor food markets. Shops and tabernae, lined up around an open square or a rectangular court, surrounded a centrally placed tholos. The latter was used as a fish shop and might have taken the form of a monopteros with columns or pillars supporting a dome or a conical roof. ${ }^{5}$ The best known examples were excavated in Puteoli, Lepcis Magna and Pompeii, all dated to the 1 st century BC to the early 2nd century AD (Lyttelton 1974, 20, 212, P1. 117; Beard 2010, 199, Fig. 14; Cristilli 2015). In all these cases, the tholoi from macella were much bigger and wider (ratio of the height to the diameter) than the presumed shrines decorating the main courtyards of the rich residences described above, e.g. the approximate diameter of the tholos in the Pompeian macellum measures around $12 \mathrm{~m}$.

The proportions (ratio of the height to the diameter) of the circular structure of the double-faced cornices resemble more or less those of the tholoi of macella, unlike its calculated size (the diameter measuring

The central building of a macellum might have been designed in various forms adapted to local needs (Cristilli 2015, 69). 
more or less $6 \mathrm{~m}$ ) which seems to be far too small for a macellum tholos of a simple monopteros form. However, if we take into account a macellum equipped with a central building of a more complex plan, like the two in Lepcis Magna (P1. 4: 2), it might turn out that the analyzed cornices could have been part of such a market. The two tholoi (their diameter of about $10 \mathrm{~m}$ ) took the form of a central octagonal building with two concentric rows of supports, external columns and internal pillars, with a slightly sloping roof stretched between them. The central part, in the middle of the internal circular colonnade, remained open to the sky. Perhaps the double-faced cornices belonged to an entablature crowning the central colonnade of such a macellum tholos.

The major doubt of this hypothesis is the place where the cornices were excavated: in Maloutena, the residential area of Nea Paphos, where no traces of a market place were discovered. If there was to be a macellum at all in Nea Paphos, for which there is no evidence (Cristilli 2015, 81-83), it seems much more likely that it would have been near the main city square, the Paphian Agora, which is located more than half a kilometer to the north from the 'Hellenistic' House.

\section{Circular structures}

There are many edifices or building complexes where a circular plan could be used. As written above, the size of the analyzed blocks indicates that the structure they were incorporated into was rather small: of a diameter around $600 \mathrm{~cm}$ and a height of more or less 260 to $300 \mathrm{~cm}$.

\section{Peristyles}

The Casa delle Quattro Stagioni in Ptolemais, Cyrenaica, also known as the Roman Villa (P1. 5: 1), constitutes a very interesting analogy with the analyzed double-faced cornices from Nea Paphos. There was a peristyle courtyard in the middle of the residence. Three out of four porticoes, the eastern, northern and western, were rectilinear. The southern portico, however, was curved like a segment of a circle, which was an arrangement similar to a shallow exedra. The curvilinear portico was taller than the others to emphasize its special role. The whole courtyard was therefore designed as a Rhodian peristyle with particular porticoes of different heights (Kraeling 1962, 119-125, Figs 43, 46, P1. XXIIa, Plans XII-XIII; Stucchi 1975, 222223, 226, 309, Figs 212, 320). Peristyles of that type were also erected on 
Cyprus - e.g. the main courtyard of the 'Hellenistic' House (BrzozowskaJawornicka forthcoming $b$ ).

The architectural embellishment of the courtyard of the Casa delle Quattro Stagioni is rich and based on combining elements of the Ionic (the columns) and Doric (the entablature) orders - a feature very characteristic of the Ptolemaic non-religious architecture (Plommer 1956, 259; Wright 1992, 51-52), not only in Alexandria or Egypt (McKenzie 2007, 89), but also in Cyrenaica (Stucchi 1975, 223, Fig. 213) or Nabataea (McKenzie 1990, P1. 119a). Examples of mixed orders are also known from Cyprus. The portico of the Amathous Agora or the tetrastylos of the 'Hellenistic' House were surmounted by the triglyph-metope frieze followed by the cornice with flat grooved modillions alternating with square hollow modillions (Vanderstar 1997, Pls DC3-4, DA2, DF1, MK 3; Brzozowska-Jawornicka forthcoming $\mathrm{a}$; forthcoming $\mathrm{b}$ ).

The radius of the curved portico is approximately $8.5 \mathrm{~m}$; its height (the colonnade with the entablature) measures around $6 \mathrm{~m}$. Although the proportions of the curved portico are different from the hypothetical circular Paphian colonnade estimated on the basis of the three doublefaced cornices (ratio of the height to the diameter: 0.35 and from 0.43 to 0.5 respectively), the general idea of the analyzed blocks belonging to a curvilinear portico seems to be more probable than any other hypothetical building listed above.

There is, however, one doubt in the theory of the double-faced cornices being a part of a portico. This question concerns the architectural decoration placed on the two opposite sides of the cornice blocks. In the case of the peristyle of the Cyrenaican residence, the inner face of the entablature, directed toward the interior of the portico, was plain without any decoration. In the back part of the cornice blocks a ledge was cut to handle the beams of the ceiling construction (Wright 1962, 220; Kraeling 1962, 125, Fig. 46). Such an arrangement was quite natural and logical - the entablature from the side of the portico interior remained in the shadow under the upper story ceiling, so it was almost invisible - there was no point in introducing any decoration there. Also the obvious but sometimes overlooked role of a cornice - protruding from the face of a wall to protect it from rainwater like eaves - does not justify placing the projecting cornice moldings inside the portico where rain could not reach them.

Thus, is there any architectural structure in which it would be reasonable to apply the double-faced cornices? 


\section{Free standing colonnade}

Hadrian's Villa, one of the most extraordinary imperial residences, is a complex estate composed of many courtyards and gardens with luxurious edifices around them built for Emperor Hadrian in the middle of the 2nd century AD. As Axel Boëthius and J. B. Ward-Perkins wrote 'Curvilinearity has become a commonplace' there (Boëthius and Ward-Perkins 1970, 254). Many buildings and courtyards in Hadrian's Villa were designed based on curved lines, e.g. in the so-called Teatro Marittimo, in the courtyard of the Piazza d'Oro pavilions or in the Accademia. In most of these cases the curvilinear structures were erected as porticoes surrounding courtyards of a flowing circumference composed of alternating curves and countercurves (Boëthius and Ward-Perkins 1970, 254-256, Fig. 100).

Like in the case of the peristyle of the Casa delle Quattro Stagioni, the curved porticoes in Hadrian's Villa do not justify the presence of decoration on both sides of the cornice. There is, however, at least one curvilinear structure in the Emperor's residence that could rationalize the usage of such elements.

The Canopus is an extensive terraced garden with a canal along its main axis in the southern part of Hadrian's Villa (P1. 5: 2). The southern end of the canal is closed with the so-called Serapeum, a monumental summer cenatio with a nymphaeum. A colonnade runs along the western and eastern edges of the long canal, single on the western side and double on the eastern side. It is curved around the northern circular end of the water basin ${ }^{6}$. The columns are surmounted by an entablature decorated on both sides - the inner directed towards the canal and the outer turned in the direction of the garden - an excellent analogy with the Paphian double-faced cornices.

Of course, one cannot expect to find a residence comparable to Hadrian's Villa in Nea Paphos. But we may wonder if perhaps a rich Paphian citizen wanted to have an extravagant garden equipped with a free-standing curvilinear colonnade supporting an entablature embellished on both sides...

\section{Summary and Conclusions}

There are at least two reasons why the three analyzed blocks constitute a very rare example of a peculiar architectural embellishment: firstly, they are decorated with different cornice moldings on the two opposite sides, and secondly, they originally belonged to a circular, rather small, low structure.

\footnotetext{
${ }^{6}$ Retrieved from http://vwhl.soic.indiana.edu/villa/canopus.php (status as of May 13th, 2018).
} 
The combination of these two features significantly reduces the number of potential analogies. The double-faced cornices originally could have been parts of one of the rich Paphian residences. They might have surmounted a curvilinear portico of a peristyle court or, what seems more probable and much more interesting, they could have crowned a free-standing colonnadea sophisticated arrangement of a residence garden. There may be also several other hypothesis concerning the nature of the original building the doublefaced cornices belonged to. Only further research and newly discovered fragments may clarify this puzzle.

\section{References}

Beard M. 2010. Pompeje. Życie rzymskiego miasta. Poznań.

Boëthius A. and Ward-Perkins J. B. 1970. Etruscan and Roman Architecture. (The Yale University Press Pelican History of Art). Harmondsworth.

Brzozowska-Jawornicka A. 2016. Reconstruction of a façade of the House of Aion, Nea Paphos, Cyprus. SAAC 20, 151-166. https://doi.org/10. 12797/SAAC.20.2016.20.10.

Brzozowska-Jawornicka A. Forthcoming a. Reconstruction of the Western Courtyard from the 'Hellenistic' House in Nea Paphos. Cyprus.

Brzozowska-Jawornicka A. Forthcoming b. The architectural orders and decoration of the 'Hellenistic' House.

Campbell G. (ed.) 2007. Classical Art and Architecture. Oxford.

Cristilli A. 2015. Macellum and Imperium. The relationship between the Roman State and the market-building construction. Analysis Archaeologica. An International Journal of Western Mediterranean Archaeology 1, 69-86.

Curtius E. and Adler F. 1894. Olympia: die Ergebnisse der von dem Deutschen Reich veranstalteten Ausgrabung. Textband 3. Die Bildwerke von Olympia in Stein und Thon. Berlin.

Czerner R. 2009. The Architectural Decoration of Marina el-Alamein. (BAR-IS 1942). Oxford.

Daszewski W.A. 1991. Polish Archaeology in the Mediterranean II (Reports 1989-1990), 78-84. Warsaw. 
Fedak J. 2006. Tombs and commemorative monuments. In F. R. Winter (ed.), Studies in Hellenistic Architecture, 71-95.Toronto.

Fuduli L. 2015. Fragmenta Paphia Elementi di decorazione architettonica. Catania.

Gros P. 1996. L'Architecture Romaine. Paris.

Hayes J. W. 1997, comment in: Hellenkemper Salies G. Römischer Wohnluxus im griechischen Osten (rev. paper of Ch. Kondoleon, Domestic and Divine. Roman mosaics in the House of Dionysos, Ithaca 1995). JRA 10, 536. https://doi.org/10.1017/S1047759400015312.

Kraeling C. H. 1962. Ptolemais City of the Libyan Pentapolis. Chicago.

Lyttelton M. 1974. Baroque Architecture in Classical Antiquity. London.

McKenzie J. 1990. The Architecture of Petra. Oxford.

McKenzie J. 2007. The Architecture of Alexandria and Egypt c. 300 BC to $A D 700$. New Haven.

Medeksza S. 1998. Willa Tezeusza w Nea Pafos na Cyprze: powstanie i fazy rozwoju. In W. A. Daszewski and H. Meyza (eds.), Cypr w badaniach polskich, 25-50. Warszawa.

Meyza H. 2015. Nea Paphos. Seasons 2012 and 2013. PAM 24/1 (Research), 443-452.

Meyza H., Romaniuk M. M. and Więch M. 2017. Nea Paphos. Season 2014 and 2016. PAM 26/1 (Research 2014-2016), 397-418.

Papuci-Wladyka E. 2008. Roman-period pottery from the eastern part of the Hellenistic House, Nea Paphos 2006. PAM 18 (Reports 2006), 524-527.

Pensabene P. 1993. Elementi architettonici di Alessandria e di altri siti egiziani. Roma.

Pesce G. 1950. Il Palazzo delle colonne in Tolemaide di Cirenaica. Roma.

Pfommer M. 1999. Alexandria. Im Schatten der Pyramiden. Mainz.

Plommer H. 1956. Ancient and Classical Architecture. London.

Rekowska M. 2012. Architectural decoration of the House of Leukaktios: Preliminary remarks. In J. Żelazowski (ed.), Ptolemais in Cyrenaica. Studies in memory of Tomasz Mikocki, 157-182. Warsaw.

Romaniuk M. M. 2017. A circular pool in the main courtyard of the "Hellenistic" House in Nea Paphos. Preliminary remarks. PAM 26/1(Research 2014-2016), 427-438.

Schmid M. 2000. Le temple d'Aphrodite à Amathonte: restitution et présentation. In G. K. Ioannidis and S. A. Hadjistyllis (eds.), Third Interna-

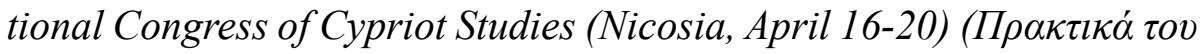

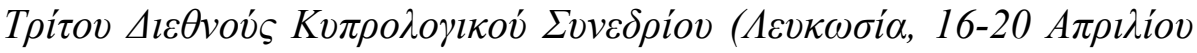
1996)), 757-767. Nicosia. 
Seiler F. 1986. Die griechische Tholos: Untersuchungen zur Entwicklung, Typologie und Funktion kunstmäßiger Rundbauten. Mainz.

Stucchi S. 1975. Architettura Cyrenaica. Roma.

Tkaczow B. 2008. Alexandrie VIII, Architectural Styles of Ancient Alexandria, Elements of Architectural Decoration from Polish Excavations at Kom el-Dikka (1960-1993). Warszawa.

Vanderstar P. 1997. The Classical Orders in Hellenistic and Roman Cyprus. D. Phil. Thesis, Oxford University.

Winter F. R. 2006. Studies in Hellenistic Architecture. Toronto.

Wright G. R. H. 1962. Construction and architectural ornament in the villa. In C. H. Kraeling (ed.), Ptolemais City of the Libyan Pentapolis, 215-225. Chicago.

Wright G. R. H. 1992. Architectural details from the Asklepeion at Balagrae (Beida). Libyan Studies 23, 45-72. https://doi.org/10.1017/ S0263718900001746.

\section{Online Sources}

Digital Hadrian's Villa Project. Retrieved from http://vwhl.soic.indiana. edu/villa/canopus.php (status as of May 13th, 2018).

Aleksandra Brzozowska-Jawornicka Faculty of Architecture Wroclaw University of Science and Technology aleksandra.brzozowska@pwr.edu.pl 

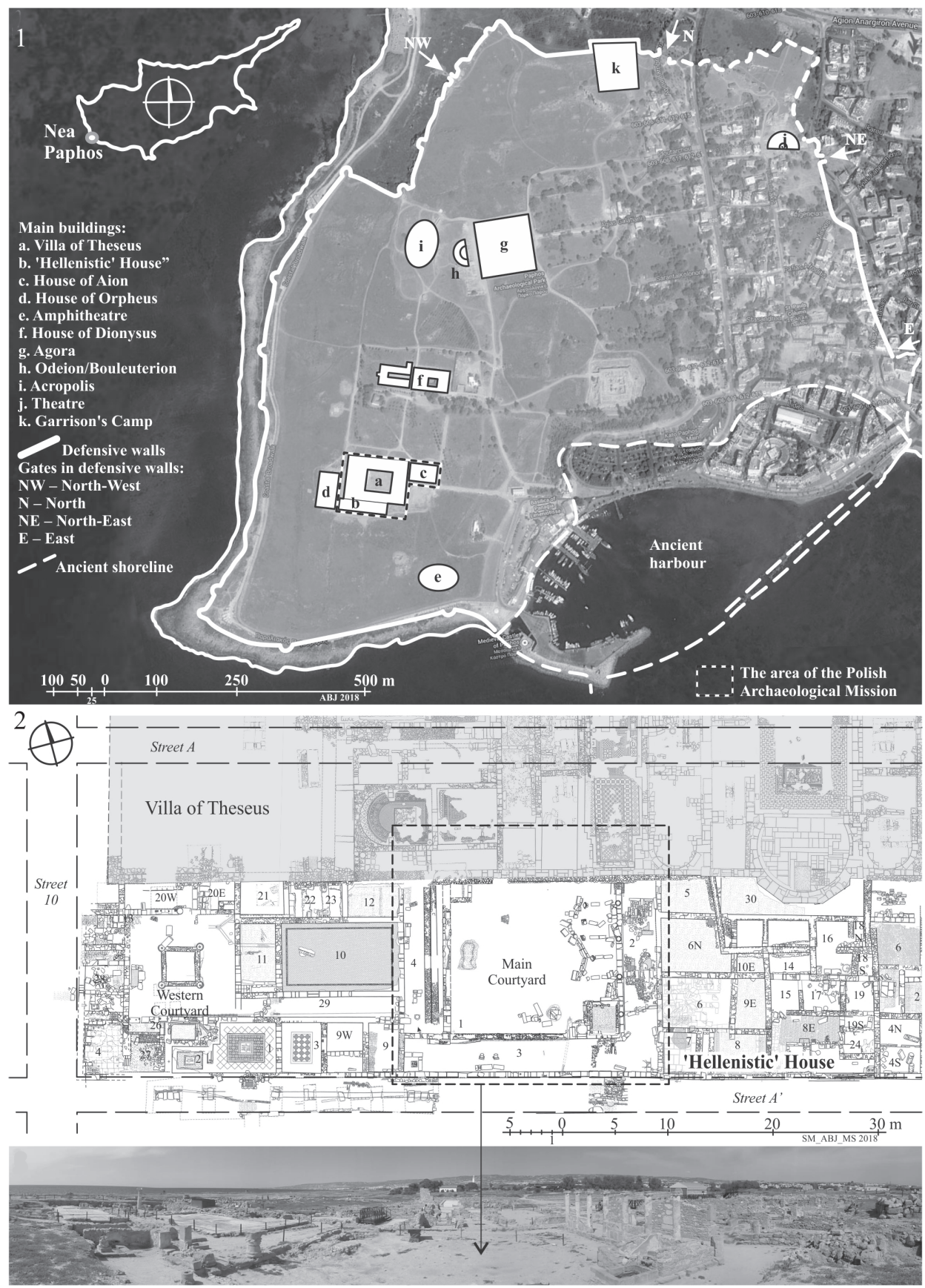

Pl. 1: 1. Plan of Nea Paphos during Hellenistic and Roman times. Based on S. Medeksza 1998, 37, Fig.1; Google Earth (status as of Oct. 5th, 2014)

P1. 1: 2. Map of the 'Hellenistic' House. Processing by S. Medeksza, M. Słowińska and A. Brzozowska-Jawornicka

P1. 1: 3. 'Hellenistic' House. Photo by author 

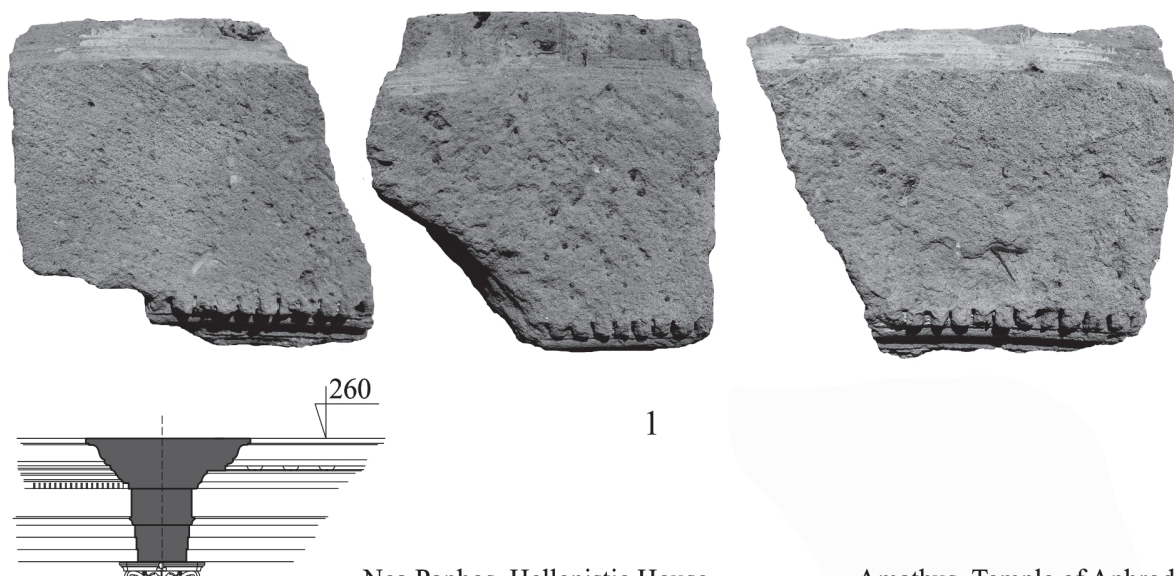

1

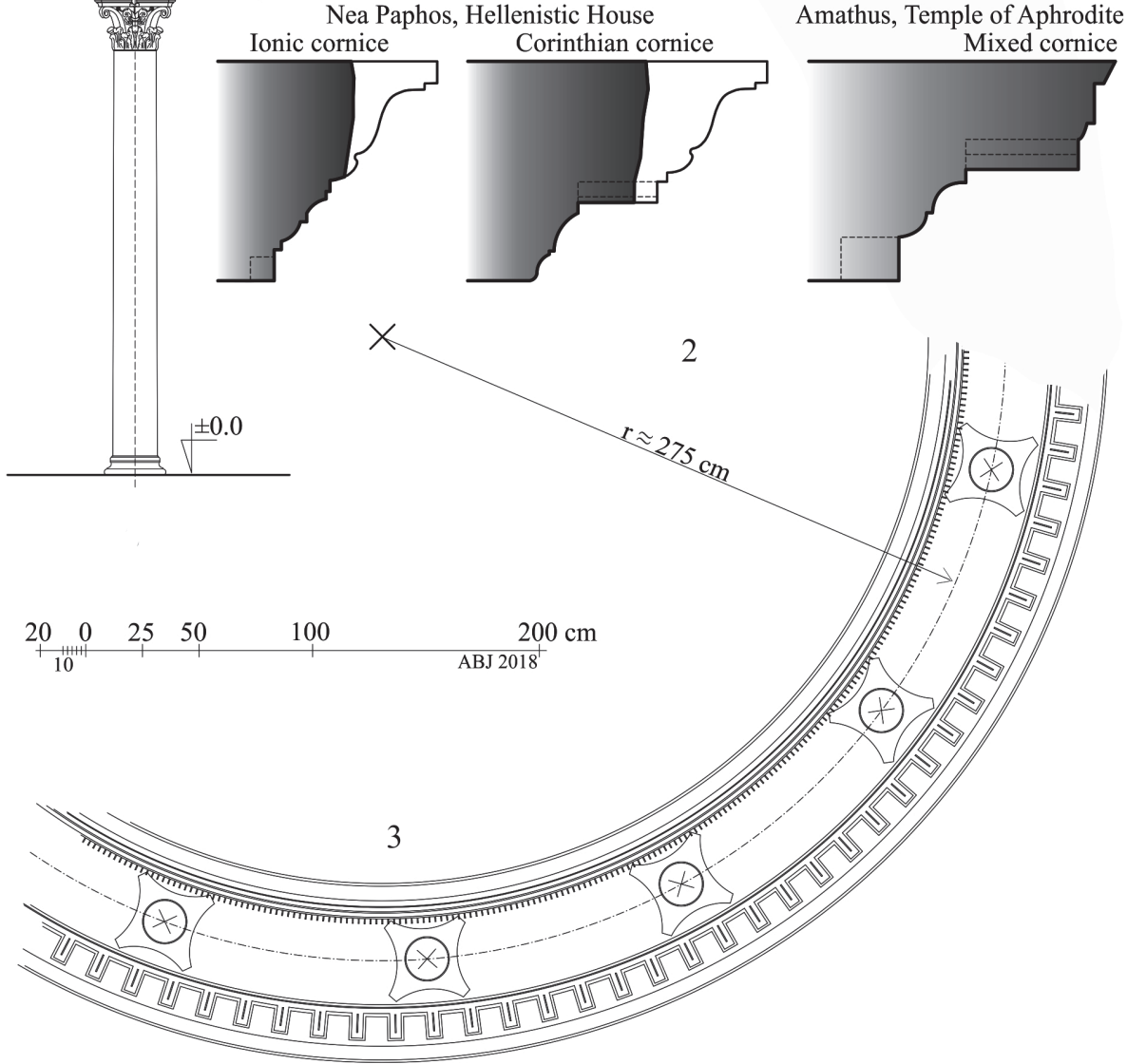

P1. 2: 1. Double-faced cornices

Pl. 2: 2. Moldings of typical cornices

Pl. 2: 3. Hypothetical circular structure. 3D models and drawing by author.

The drawing of the mixed cornice based on M. Schmid 2000, 761, Fig. 3 

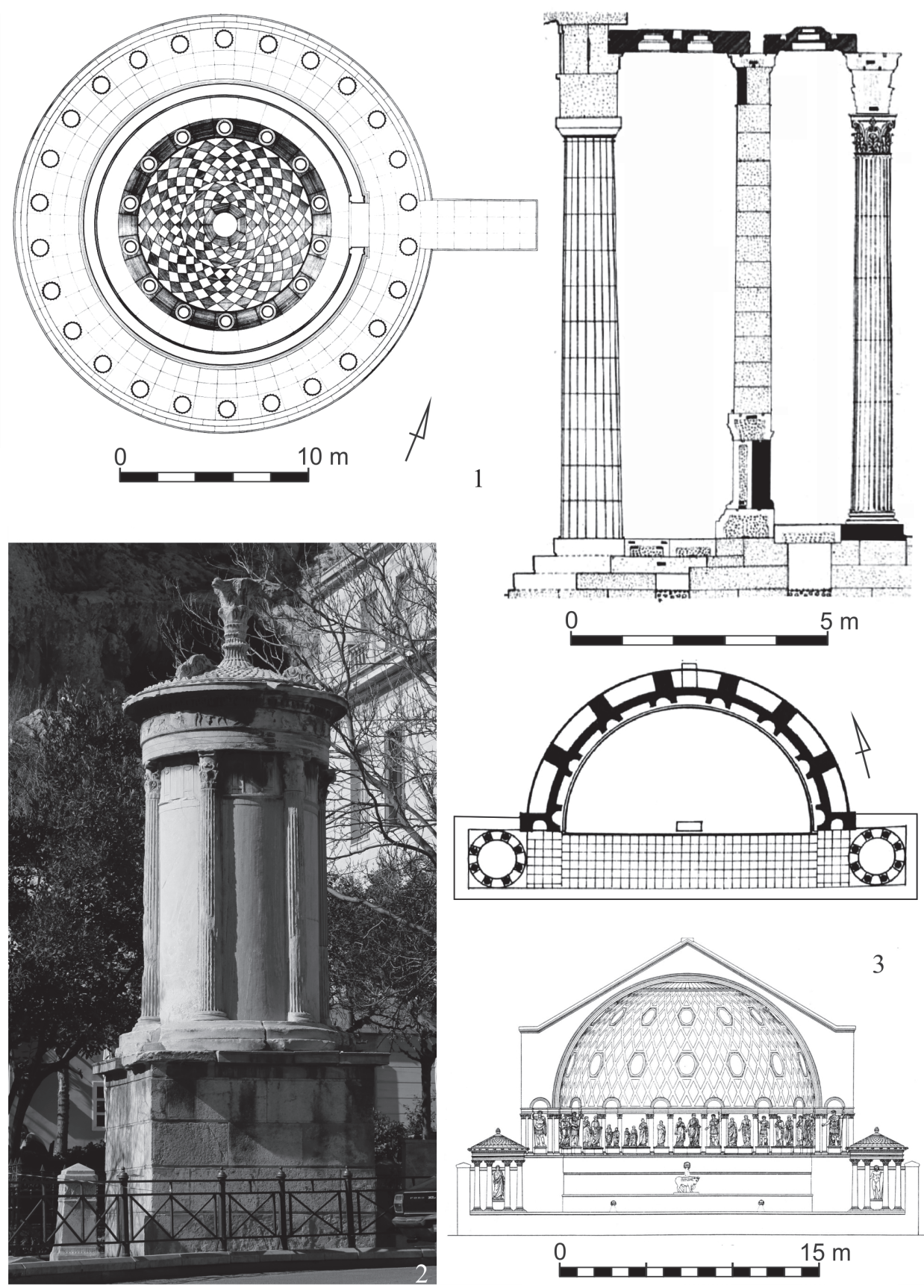

P1. 3: 1. Plan and section of the Tholos at Epidauros. Reproduced from Winter 2006, 378, Figs 189-190

Pl. 3: 2. The choragic Monument of Lysicrates in Athens. Photo by author

Pl 3: 3. Nymphaeum in Olympia. Reproduced from Curtius \& Adler 1894, 262, 266, Figs 294, 298. 

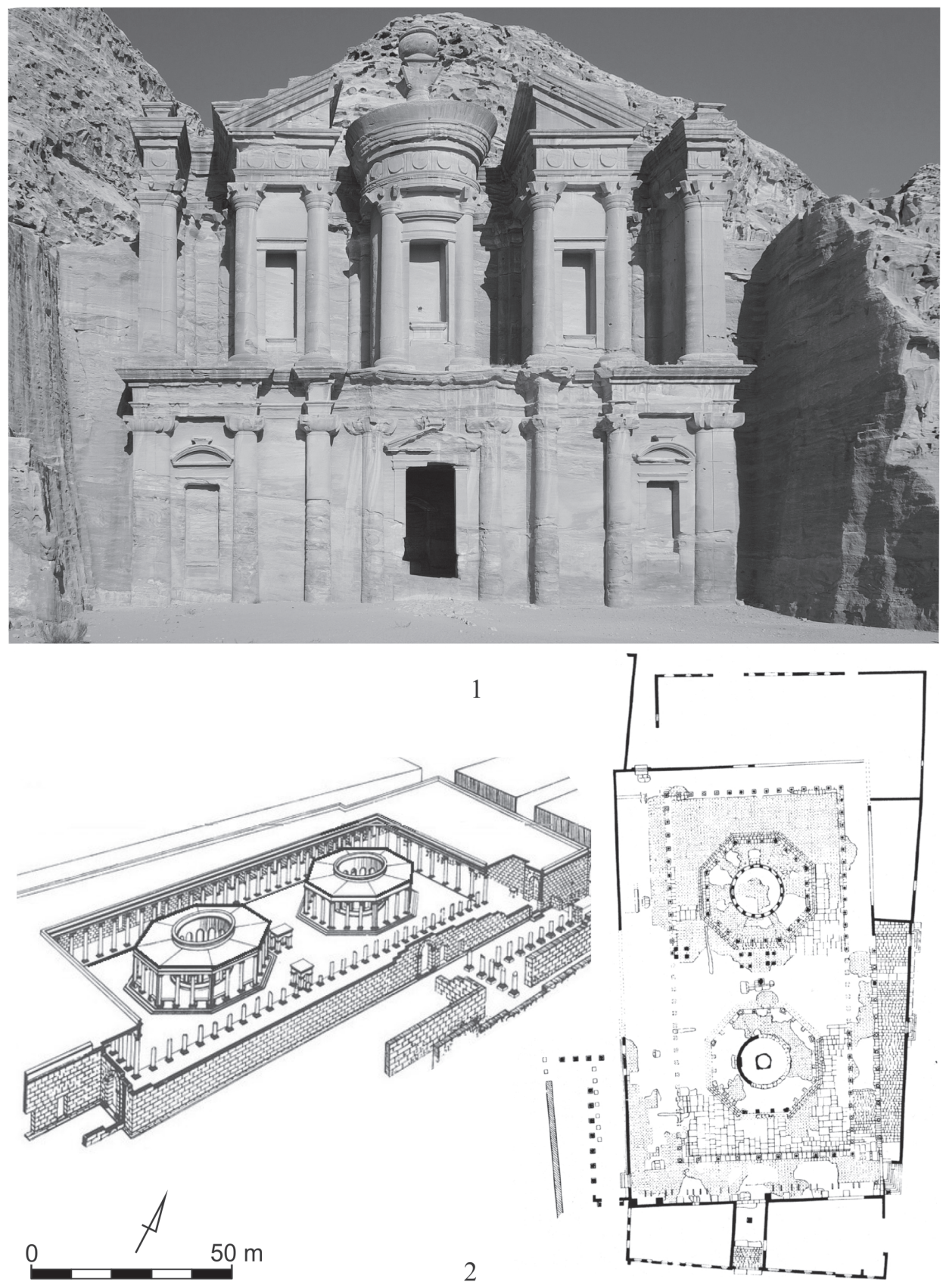

Pl. 4: 1. The Deir, Petra. Phot. M. Kwaśnik

Pl. 4: 2. Macellum in Lepcis Magna. Reproduced from Gros 1996, 454-455, Figs 507-508 

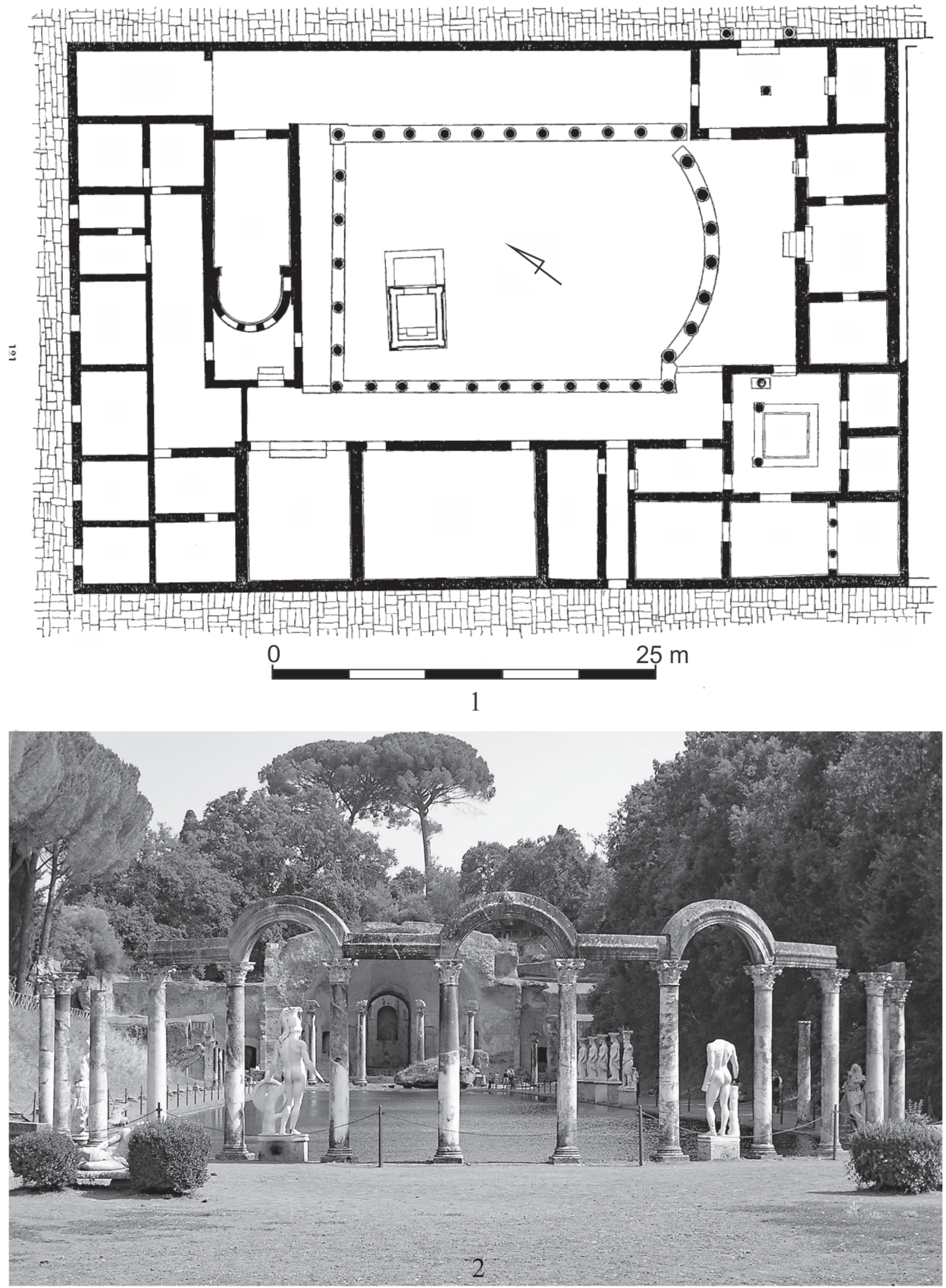

Pl. 5: 1. Plan of the Casa delle Quattro Stagioni, Ptolemais.

Reproduced from Kraeling 1962, 121, Fig. 43

P1. 5: 2. Canopus in the Hadrian's Villa. Phot. https://pixabay.com/pl/villa-adriana-willaadriana-tivoli-2323004/ (status as of May 13th, 2018) 